Article

\author{
F. M. Raimondo, G. Domina \& E. Di Gristina
}

\title{
Unpublished aspects of hygrophilous wood vegetation from Nebrodi Mountains (N-E Sicily)
}

\begin{abstract}
Raimondo, F. M., Domina, G., Di Gristina, E.: Unpublished aspects of hygrophilous wood vegetation from Nebrodi Mountains (N-E Sicily). — Fl. Medit. 31 (Special Issue): 145-167. 2021. — ISSN: 1120-4052 printed, 2240-4538 online.

In this paper we report the results of a study done on the vegetation of hygrophilous woods and shrubs occurring along the sub montane and montane small rivers of the Alcantara watershed located in the Nebrodi Mountains (N-E Sicily). We have described two new associations: Alno glutinosae-Salicetum rubentis and Euonymo europaei-Salicetum lambertianae, both belonging to the class Salici purpureae-Populetea nigrae. The forest association would belong to the alliance Populion albae of the order Populetalia albae, while the shrubs of pebbly streams would give origin to communities that would belong to the alliance Salicion albae of the order Salicetalia purpureae. The study gave the occasion to produce a new syntaxonomic framework of this vegetation.

Key words: riparian vegetation, plant sociology, syntaxonomy, Salici purpureae-Populetea nigrae, Sicily, Italy.
\end{abstract}

\section{Introduction}

Nebrodi Mountains are the largest mountain system in Sicily. They represent the southward extension of the Apennine chain. The system goes from east to west along the Tyrrhenian coast of the island and culminates with Mount Soro (1847 m a.s.1.). Climatically the area is subjected to temperate variations of the Mediterranean climate. In particular, over $1000 \mathrm{~m}$ a.s.l. the sub-Mediterranean subclimate prevails, with annual rainfall above $1000 \mathrm{~mm}$ and with recurring snowfall in January-February. Forest vegetation - still well represented - is distributed in altitudinal belts. The first belt is constituted by Mediterranean maquis (Pistacio-Rhamnetalia alaterni), the second by the temperate Mediterranean forest with Quercus ilex or Q. suber (Quercetalia ilicis), the third by the submontane forest with deciduous oaks (Quercetalia pubescentis-petraeae), to last by the mountain forest with Fagus sylvatica and Acer pseudoplatanus (Fagetalia sylvaticae). It is the same physiognomic vegetation occurring in Mediterranean and Apennine Italy, but in Sicily the species of local flora substitute the species of southern Europe and many of those of the South Italian 
Peninsula.In their study on the arboreal and arborescent vegetation of the margins of water courses of Sicily Brullo \& Spampinato (1990), considered also the Nebrodi Mountains, however, submontane and mountain areas still remained unexplored. This vegetation is characterized by species of willows (Salix sp. pl.), poplars (Populus nigra) and the black alder (Alnus glutinosa), the latter in Sicily assumes a considerable role in the Nebrodi Mountains. Thanks to its presence, the submontane and montane riparian formations of Nebrodi Mountains resulted physionomically very similar to the associations described by Barbagallo \& al. (1982) for the southern Apennines and in particular to those described by Brullo \& Spampinato (1997) and Brullo \& al. (2001) in Calabria. With this study we wanted to analyse in deep the phytosociology and the syntaxonomy of the hygrophilous vegetation characterized by these species. We examined not only the tree formations traditionally referred to the order Populetalia albae, but also those arborescent dominated by Salix purpurea subsp. lambertiana and, therefore, referred to the order Salicetalia purpureae. Since this hygrophilous vegetation in Sicily is found exclusively in the submontane and mountainous belt of the Alcantara river basin of the Nebrodi Mountains and since for this type of vegetation we were able to define two new associations, we have been induced to reconsider the syntaxonomical scheme of the hygrophilous woody vegetation of Sicily and to propose a new one.

\section{The environmental context of the Nebrodi Mountains}

The Nebrodi chain is placed in the north-eastern part of Sicily (Fig. 1). The upper part is a very extensive mountain area and also rich in forest vegetation (Domina \& al. 2018). This richness is a consequence of copious rainfall - also of a snowy nature - and of the heterogeneity of the hydrogeological structure of the area which includes rivers that flow both to Tyrrhenian and the Ionian sides (Giaimi 1994). The general morphology of this area is given by rounded peaks, plateaus and slopes, with peaks often exceeding $1000 \mathrm{~m}$ (a.s.1.). The superficial hydrographic network is mainly torrential, referable to the sub dendritic type, in addition there is the head incisions that flow into the Alcantara and Simeto rivers. Of these, the most important are the Favoscuro stream, the Flascio river, the Saracena stream and the Inganno stream, all running approximately North West-South East (Giaimi 1994). The climate of the Nebrodi mountain system is one of the wettest sectors in Sicily, with summer aridity limited to the months of June-August. According to Bagnouuls \& Gaussen's classification (1957), the part of the territory below $1200 \mathrm{~m}$ (a.s.1.) belongs to the Mesomediterranean type and, above, to the Submediterranean one (Brullo \& Grillo 1978). In light of the fact that the system has its maximum elevation in Monte Soro (1847 $\mathrm{m}$ a.s.1.) and that a substantial part of the territory lies within the altimetric space between $1200 \mathrm{~m}$ and the top of this mountain, the space subject to the subMediterranean climatic type is very extended. On the basis of the data collected in the weather station of Floresta (1275 m a.s.1.) (Fig. 1) - close to the area investigated the corresponding climatic diagram, according to Walter \& Lieth (1960), reveals a dry period of 2-3 months included in summer months (Fig. 2). 


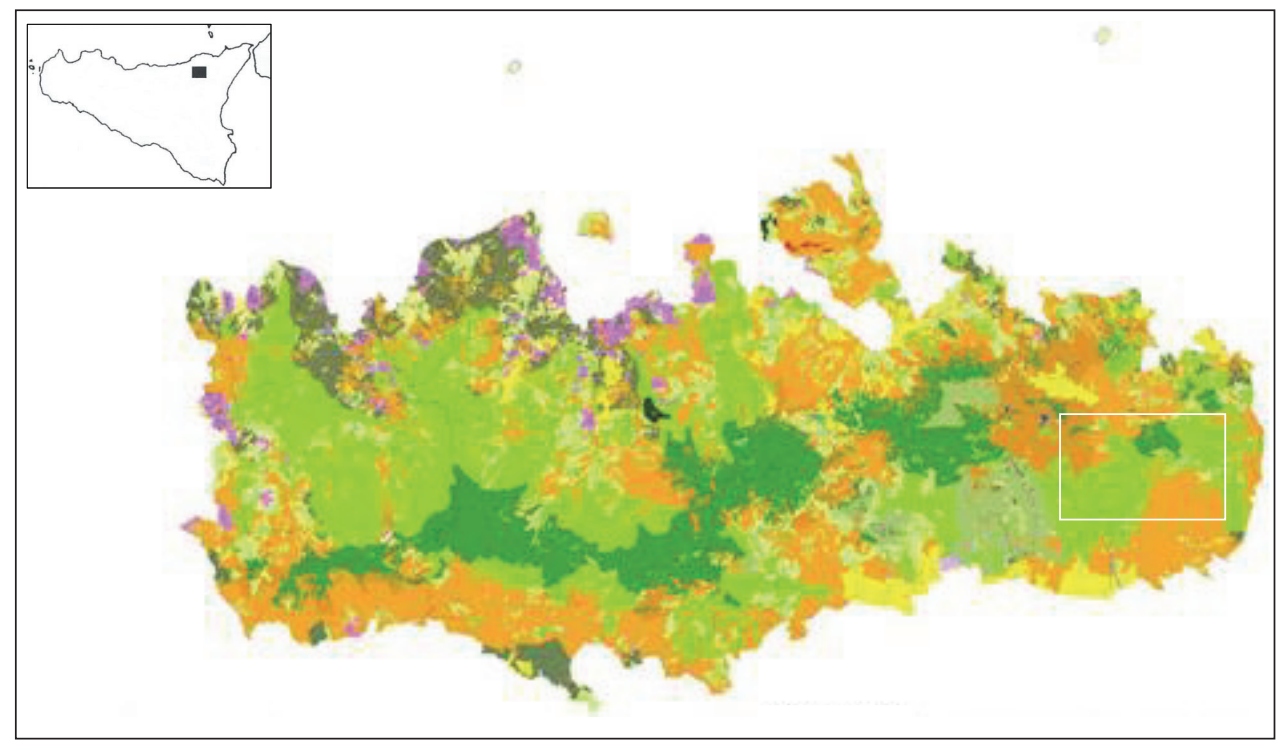

Fig. 1. The territory of the Nebrodi Natural Park in Sicily: evident the diversity of vegetation. In the box on the right, the location of the area investigated (from an unpublished document of the former Laboratory of Systematics, Phytogeography and Plant Ecology of the University of Palermo).

The average annual rainfall recorded in Floresta is over 1300-1400 mm. The precipitations are mainly distributed in the autumn-winter period. Average annual temperatures are comprised between $10-13{ }^{\circ} \mathrm{C}$. The lowest of the whole area are recorded in Floresta where in January the average is $-1{ }^{\circ} \mathrm{C}$. In this station, the absolute lowest temperature of $-17.4{ }^{\circ} \mathrm{C}$ was recorded, while the maximum values were recorded in July, with an average of 19.2 ${ }^{\circ} \mathrm{C}$ and extreme values of $33^{\circ}-36.5^{\circ} \mathrm{C}$. As observed by Brullo \& Grillo (1990), an important factor is represented by snowfall, with one meter of snow falling in an average of 20 days, particularly in January and February. The duration of snow cover is maximum in the higher parts where it can last even for longer periods. According to the bioclimatic classification introduced by Rivas-Martínez $(1981,1982)$ we are in the Supramediterranean belt, with a temperate Supramediterranean thermotype and Lower sub humid conditions (Bazan $\&$ al. 2015). These data justify the presence of extensive mesophilous forest and the presence, in the mountain part, of streams and canals flowing towards the valley, feeding also in summer the main branches of the watercourses that originate from the eastern side of Nebrodi Mountains, with a permanent water flow, although reduced in summer.

The natural vegetation of Nebrodi Mountains has undergone deep transformations over time. The millenary anthropic activities have determined a substantial reduction of the original forest surface and an increase of the aspects of degradation of itself. However, even today, this territory owns an extensive and rich forest heritage of natural and landscape interest (Karadelev \& al. 2017), elements that together contribute to enhance the environmental value of the entire Sicilian territory. 


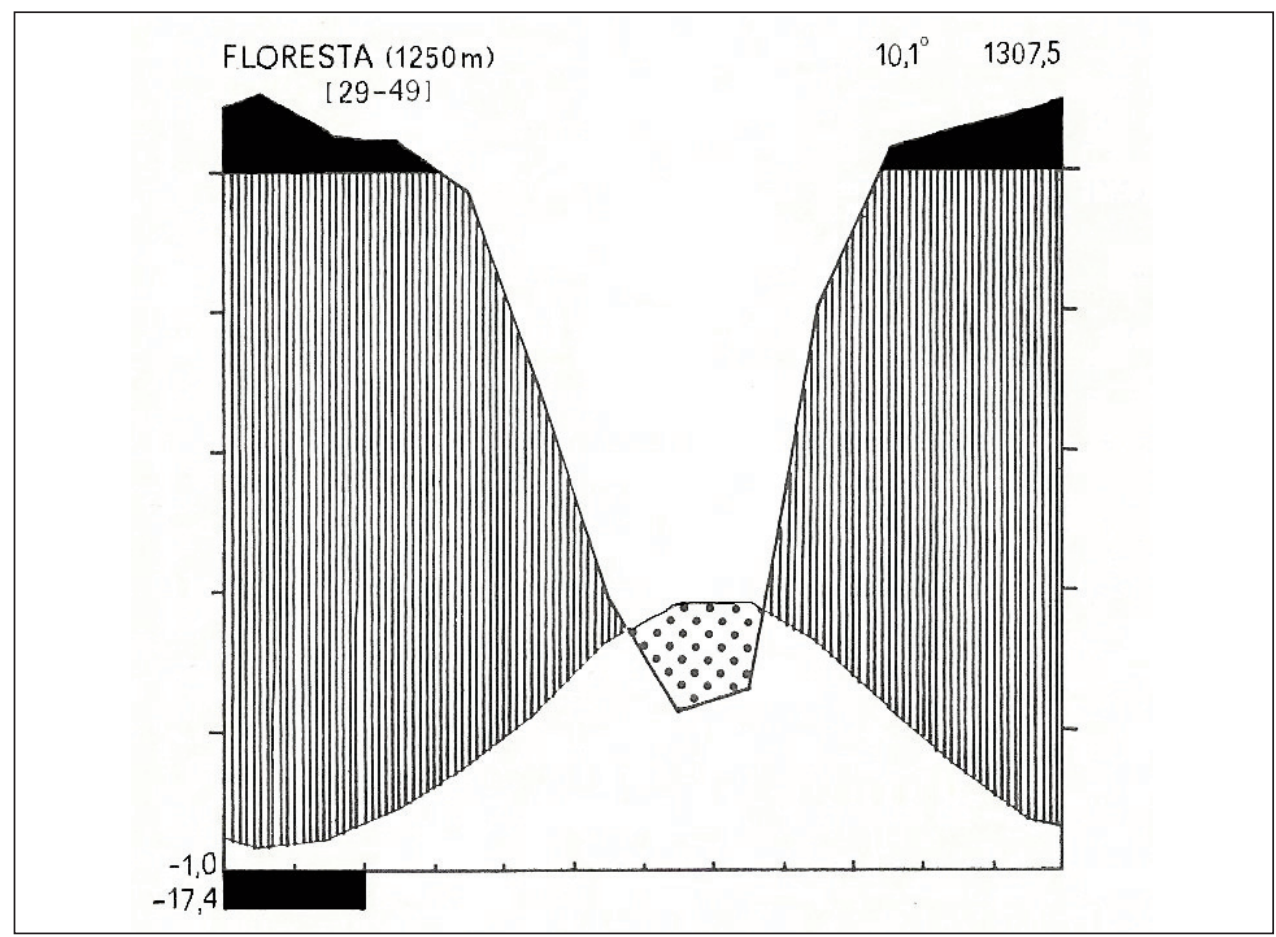

Fig. 2. Floresta weather station (Nebrodi Mountains) (from Brullo \& Grillo 1978).

\section{The study area}

The investigation area is limited to the eastern part of the Nebrodi system which borders with the Etna area to the east and south-east, and with the Peloritani Mountains to the north-east. It is located almost entirely within the territory of Floresta (Fig. 1), the highest inhabited centre in Sicily (1275 m a.s.1.). Meaningful reliefs in this sector are: Monte Colla (1610 m a.s.1.), Monte Solazzo (1539 m a.s.1.), Monte del Moro (1433 m a.s.1.), Monte di Pietre Bianche (1523 m a.s.1.), Monte Bissalacqua (1424 m a.s.1.), Pizzo Randazzo Vecchio (1420 m a.s.1.), ecc. (see Fig. 3).

\section{Data and Methods}

The vegetation examined was that of the small streams in the upper Alcantara river basin, downstream of the northern slopes of Mounts Acquafredda (1447 m a.s.1.), Colla (1611 m a.s.1.), Musarra (1257 m a.s.1.), Pietre Bianche (1523 m a.s.1.) and the southern slopes of Monte Azzarello (1289 m a.s.1.), in the territory of Floresta (Fig. 3), space occupied by deciduous oaks with dominance of $Q$. cerris (Quercion pubescentis-petraea) below and thermophilous beech forests (Geranio versicoloris-Fagion) upward, but also from widespread coniferous forest systems, in the altitude range 1000-1600 m (a.s.1.). The 


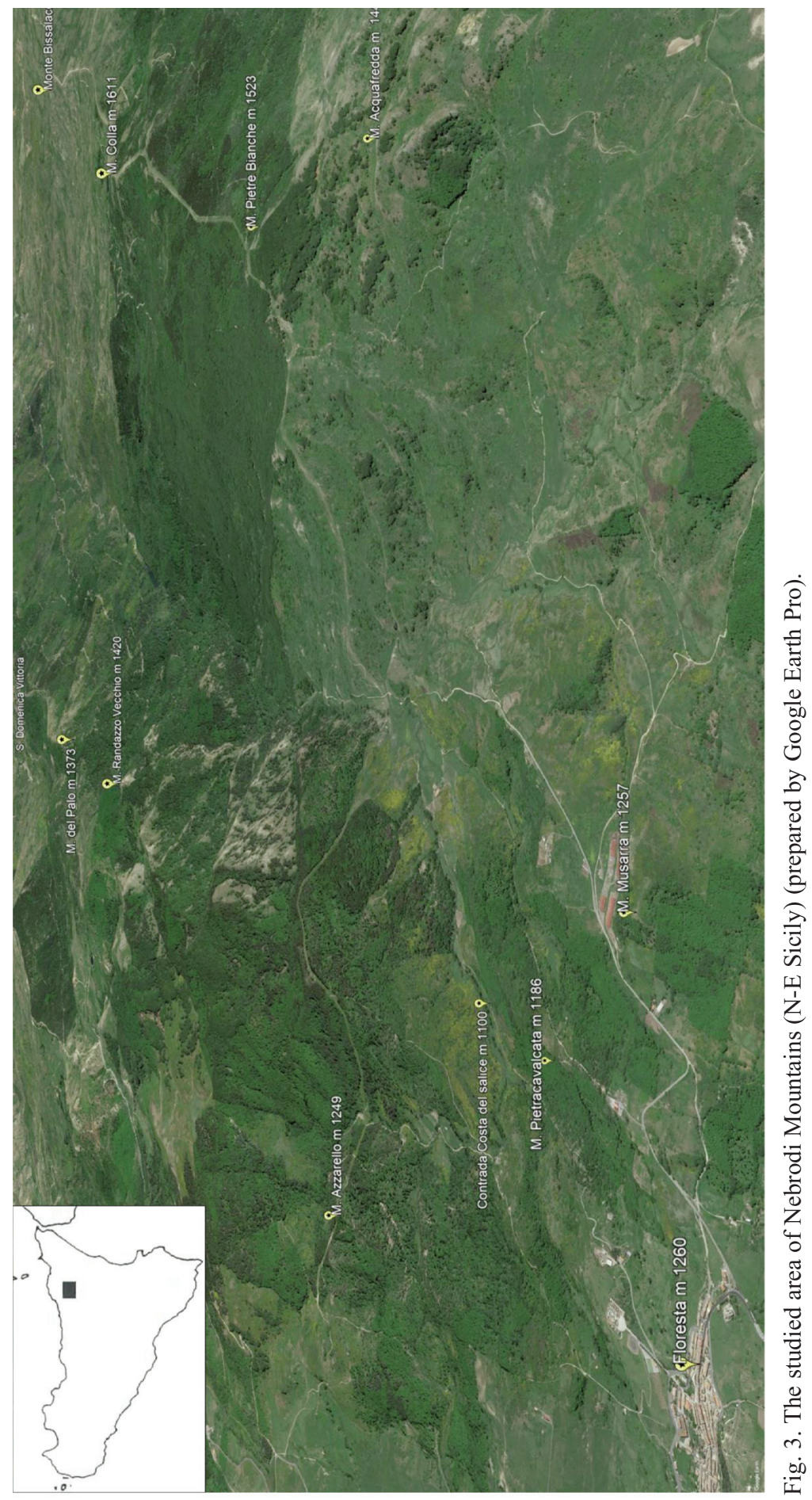


vegetation survey was carried out in summer, following the phytosociological method of the Zurich-Monpellier school.

The individual surveys have been brought together in two distinct tables, for the forest aspects (Table 1) and for the arborescent aspects (Table 4), respectively. The nomenclature of the plants cited in tables, text and appendix follows the portal to the flora of Italy (http://dryades.units.it/floritaly/index.php), except a few cases. The complete list of the taxa cited in the test and tables is presented in the electronic supplement. Furthermore, both for biological categories and for chorological types, we have followed the nomenclature used by Raimondo \& al. (2010).

The phytosociological classification of the vegetation analyzed here, is referred to the syntaxa units recognized by Biondi \& al. (2014) which are also followed for the nomenclature of the mentioned syntaxa in the text and in the Electronic Supplementary File (ESF1a). The nomenclature of the plants cited in text, captions, tables, and ESF1b follows Bartolucci \& al. (2018), except a few cases. Furthermore, both for biological categories and for chorological types, reference is made to Raimondo \& al. (2010). The reunion in six contingents of the numerous chorological types occurring in the phytosociological tables, follows Di Martino \& Raimondo (1979). The calculation of the qualitative and quantitative spectra of the biological and chorological categories is based on the same criterion used by the aforementioned authors in their previous study in Sicily (Di Martino \& Raimondo 1976).

To compare the studied vegetation and calculate its similarity between associations of the same type in southern Italy and Sicily, in terms of frequency classes of the species, we have used the formula of similarity ratio that for binary data it is the well known formula of Jaccard (Podani 2000) namely the ratio between the intersection and the union of two sets.

\section{Results}

On the basis of the floristic comparisons with the syntaxa described by some authors for Southern Italy and Sicily, and also accepted by Biondi \& al. (2014) we have defined two new associations: Alno glutinosae-Salicetum rubentis and Euonymo europaei-Salicetum lambertianae. These two associations are described considering several points of view as follows.

Alno glutinosae-Salicetum rubentis Raimondo, Domina \& Di Gristina ass. nov. hoc loco (Table 1)

Type: Rel. 5 in Table 1 (geographic coordinates: 3757’31,03”N/1454'53,95”E).

This association includes strips of woods on narrow depressions with limited flowing water (Fig. 5d) even during the summer (Fig. 5f). Sometimes, in the flat stretches of the same stream where the riverbed expands, this association is replaced by the EuonymoSalicetum lambertianae the other new association that we describe below.

Characteristic species - Salix $\times$ rubens (Fig. 5c), plant characterizing this association is a nothospecies never mentioned before in phytosociological studies in Sicily and in others Italian and Mediterranean regions. Other characteristics are: Rhyncochoris elephas (Fig. 
Table 1. Phytosociological table of Alno-Salicetum rubentis ass. nov.

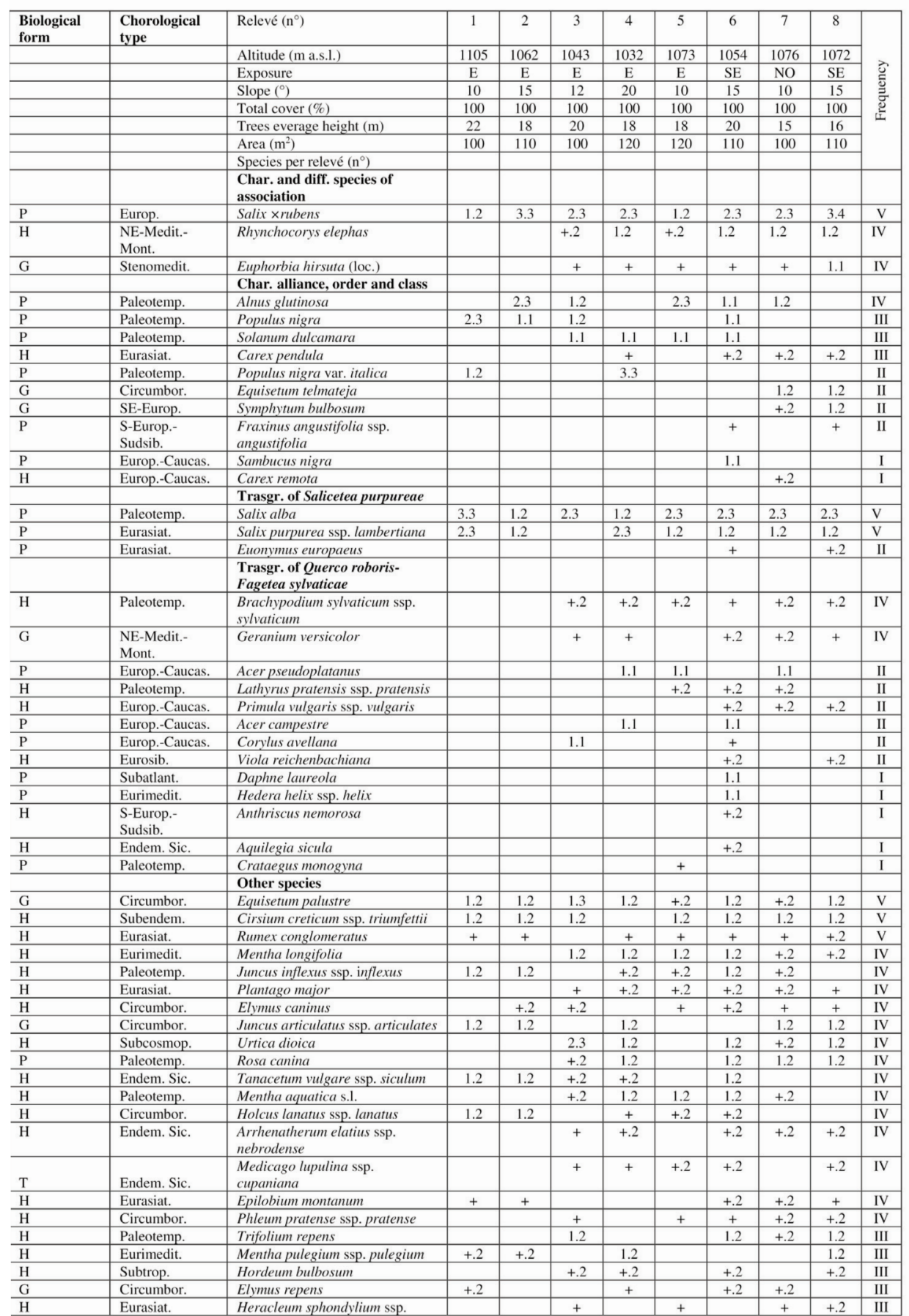


Table 1. continued.

\begin{tabular}{|c|c|c|c|c|c|c|c|c|c|c|c|}
\hline & & elegans & & & & & & & & & \\
\hline $\mathrm{P}$ & Eurimedit. & Rubus ulmifolius & & & & & & 1.2 & 1.2 & 1.2 & II \\
\hline $\mathrm{H}$ & $\begin{array}{l}\text { Eurimedit.- } \\
\text { Subatl. }\end{array}$ & Oenanthe pimpinelloides & 1.2 & 1.2 & & & + & & & & II \\
\hline $\mathrm{H}$ & Eurosib. & Juncus conglomeratus & +.2 & +.2 & & & & & & +.2 & II \\
\hline $\mathrm{H}$ & Europ.-Caucas. & Cynosurus cristatus & & & +.2 & & +.2 & +.2 & & & II \\
\hline $\mathrm{H}$ & Eurimedit. & $\begin{array}{l}\text { Helosciadium nodiflorum ssp. } \\
\text { nodiflorum }\end{array}$ & & & & +.2 & +.2 & +.2 & & & II \\
\hline $\mathrm{H}$ & W-Medit. & Oenanthe globulosa ssp. kunzei & & & & & & +.2 & +.2 & +.2 & II \\
\hline $\mathrm{H}$ & Endem. & Taraxacum siculum & & & & & & +.2 & +.2 & +.2 & II \\
\hline $\mathrm{H}$ & Eurimedit. & Dipsacus fullonum & + & + & & + & & & & & II \\
\hline $\mathrm{H}$ & W-Medit. & Cirsium vulgare ssp. crinitum & + & + & & & & & + & & II \\
\hline G & Cosmopol. & $\begin{array}{l}\text { Pteridium aquilinum ssp. } \\
\text { aquilinum }\end{array}$ & & & 1.2 & 1.2 & & & & & II \\
\hline $\mathrm{H}$ & & Trifolium $\mathrm{sp}$. & & & 1.2 & 1.2 & & & & & II \\
\hline $\mathrm{H}$ & Paleotemp. & $\begin{array}{l}\text { Lolium arundinaceum ssp. } \\
\text { arundinaceum }\end{array}$ & & & & 1.2 & +.2 & & & & II \\
\hline $\mathrm{P}$ & & Rubus sp. & & & 1.2 & & & + & & & II \\
\hline $\mathrm{H}$ & N-Eurimedit. & Ranunculus velutinus & & & & & & 1.1 & +.2 & & II \\
\hline $\mathrm{T}$ & Stenomedit. & Calepina irregularis & & & & & & & +.2 & 1.2 & II \\
\hline $\mathrm{H}$ & Paleotemp. & Potentilla reptans & +.2 & +.2 & & & & & & & II \\
\hline $\mathrm{H}$ & Circumbor. & Lolium perenne & & & & +.2 & & +.2 & & & II \\
\hline $\mathrm{H}$ & Paleotemp. & Ranunculus repens & & & & & +.2 & +.2 & & & II \\
\hline $\mathrm{H}$ & Paleotemp. & Alliaria petiolata & & & & & & & +.2 & +.2 & II \\
\hline $\mathrm{P}$ & Europ.-Caucas. & Prunus spinosa ssp. spinosa & & & & & & & +.2 & +.2 & II \\
\hline $\mathrm{T}$ & Subcosmop. & Torilis arvensis ssp. arvensis & & & + & +.2 & & & & & II \\
\hline $\mathrm{H}$ & S-Stenomedit. & Barbarea bracteosa & & & & & & & +.2 & + & II \\
\hline G & Stenomedit. & $\begin{array}{l}\text { Dactylorhiza maculata ssp. } \\
\text { saccifera }\end{array}$ & & & & & + & + & & & II \\
\hline $\mathrm{H}$ & Eurasiat. & $\begin{array}{l}\text { Veronica beccabunga ssp. } \\
\text { beccabunga }\end{array}$ & & & & & & 1.2 & & & I \\
\hline $\mathrm{G}$ & Paleotemp. & Tussilago farfara & & & & +.2 & & & & & $\mathrm{I}$ \\
\hline I & Subcosmop. & Glyceria fluitans & & & & +.2 & & & & & I \\
\hline $\mathrm{H}$ & Paleotemp. & Epilobium hirsutum & & & & & +.2 & & & & $\mathrm{I}$ \\
\hline $\mathrm{T}$ & S Amer. & Capsella rubella & & & & & & +.2 & & & $\mathrm{I}$ \\
\hline $\mathrm{T}$ & & Crepis sp. & & & & & & +.2 & & & I \\
\hline $\mathrm{T}$ & $\begin{array}{l}\text { Eurimedit.- } \\
\text { Subatl. }\end{array}$ & Crepis vesicaria & & & & & & +.2 & & & I \\
\hline $\mathrm{H}$ & Paleotemp. & Dactylis glomerata & & & & & & +.2 & & & I \\
\hline $\mathrm{H}$ & Eurimedit. & Galium palustre ssp. elongatum & & & & & & +.2 & & & I \\
\hline $\mathrm{H}$ & Eurosib. & Trifolium pratense & & & & & & +.2 & & & I \\
\hline $\mathrm{H}$ & Cosmopol. & Veronica anagallis-aquatica & & & & & & +.2 & & & I \\
\hline $\mathrm{T}$ & Eurasiat. & Sonchus asper & & & & + & & & & & $\mathrm{I}$ \\
\hline $\mathrm{H}$ & Stenomedit. & Carex distachya & & & & & + & & & & I \\
\hline $\mathrm{H}$ & Paleotemp. & Cichorium intybus & & & & & + & & & & I \\
\hline $\mathrm{Ch}$ & Endem. Sic. & Euphorbia gasparrinii & & & & & + & & & & $\mathrm{I}$ \\
\hline $\mathrm{H}$ & Stenomedit. & Hypericum perfoliatum & & & & & + & & & & I \\
\hline $\mathrm{P}$ & $\begin{array}{l}\text { S-Europ.- } \\
\text { Pontico }\end{array}$ & Prunus mahaleb & & & & & + & & & & I \\
\hline $\mathrm{H}$ & Eurimedit. & Arctium minus & & & & & & + & & & I \\
\hline $\mathrm{H}$ & Europ.-Caucas. & Bellis perennis & & & & & & + & & & $\mathrm{I}$ \\
\hline $\mathrm{T}$ & Subcosmop. & Bromus hordeaceus & & & & & & + & & & $\mathrm{I}$ \\
\hline $\mathrm{P}$ & & Ulmus sp. & & & & & & + & & & I \\
\hline
\end{tabular}

5e), and Euphorbia hirsuta.

The first is a rare north-western Mediterranean-mountain element - in Sicily occurring in other different hygrophilous plant communities (Brullo \& Grillo 1978; Gianguzzi \& al. 2004); the second is quite frequent in our vegetation stands and it is also mentioned, together with Apium graveolens and Alnus glutinosa in the Apio graveolentis-Alnetum glutinosae, association from Corsica, that belongs to the Alnion glutinosae (Alnetalia and Alnetea glutinosae) (see Reymann \& al. 2016).

Floristic organization - The association consists basically of four species: Alnus glutinosa, Populus nigra, Salix alba and S. ×rubens (Figs. 4 a-c and 5a-b). To these, 
in the tree layer, occasionally is present Fraxinus angustifolia subsp. angustifolia, Acer pseudoplatanus, A. campestre; Salix purpurea subsp. lambertiana is frequent in the shrubby layer in which occurs also Rosa canina, Crataegus monogyna and, occasionally, Euonymus europaeus. The suffruticose and herbaceous layer comprises many species, including Euphorbia hirsuta, Equisetum palustre, E. telmateja, Mentha aquatica, M. longifolia, M. pulegium, Carex pendula, C. remota, Ranunculus repens, some grasses (Holcus lanatus, Phleum pratense, Arrhenatherum elatius subsp. nebrodense, Elymus caninus, E. repens, Hordeum bulbosum), Epilobium hirsutum, Heracleum spondylium subsp. elegans, J. conglomeratus, J. articulatus subsp. articulatus, Trifolium fragiferum, Plantago major, Potentilla reptans, Barbarea bracteosa (see Table 1).

Biological and biogeographical structure - The examined association consists of species belonging to different biological categories, among which, the hemicryptophytes $(55.2 \%$ and $58,0 \%)$ and the phanerophytes $(23.9 \%$ and $23.6 \%$ ) (Table 2, Fig. 6a) play the fundamental role, both qualitatively and quantitatively. The phanerophytes are defining the structure of the vegetation of the proposed association (Table 2, Fig. 6b).

From the biogeographical point of view, the florula is represented by numerous chorological types (chorotypes). The Mediterranean (45.6\% and $46.1 \%)$ and the boreal chorotypes (33.7\% and 37.9\%) (Table 3, Fig. 6c) play a considerable role (Table 3, Fig. 6d); the regional endemism are absent.

Table 2. Data of biological spectra of Alno-Salicetum rubentis.

\begin{tabular}{|l|l|l|}
\hline Biological forms & florula\% & vegetation\% \\
\hline H & 55.2 & 58.0 \\
\hline P & 23.9 & 23.6 \\
\hline G & 10.4 & 12.8 \\
\hline T & 8.3 & 5.0 \\
\hline Ch & 1.1 & 0.3 \\
\hline I & 1.1 & 0.3 \\
\hline
\end{tabular}

Table 3. Data of chorological spectra of Alno-Salicetum rubentis.

\begin{tabular}{|l|c|c|}
\hline Chorological contingents & florula \% & vegetation \% \\
\hline Mediterranean & 45.6 & 46.1 \\
\hline Boreal & 33.7 & 37.9 \\
\hline Oriental & 6.5 & 6.0 \\
\hline Cosmopolitan & 6.5 & 4.3 \\
\hline Western & 5.4 & 3.9 \\
\hline Meridional & 2.3 & 1.8 \\
\hline
\end{tabular}



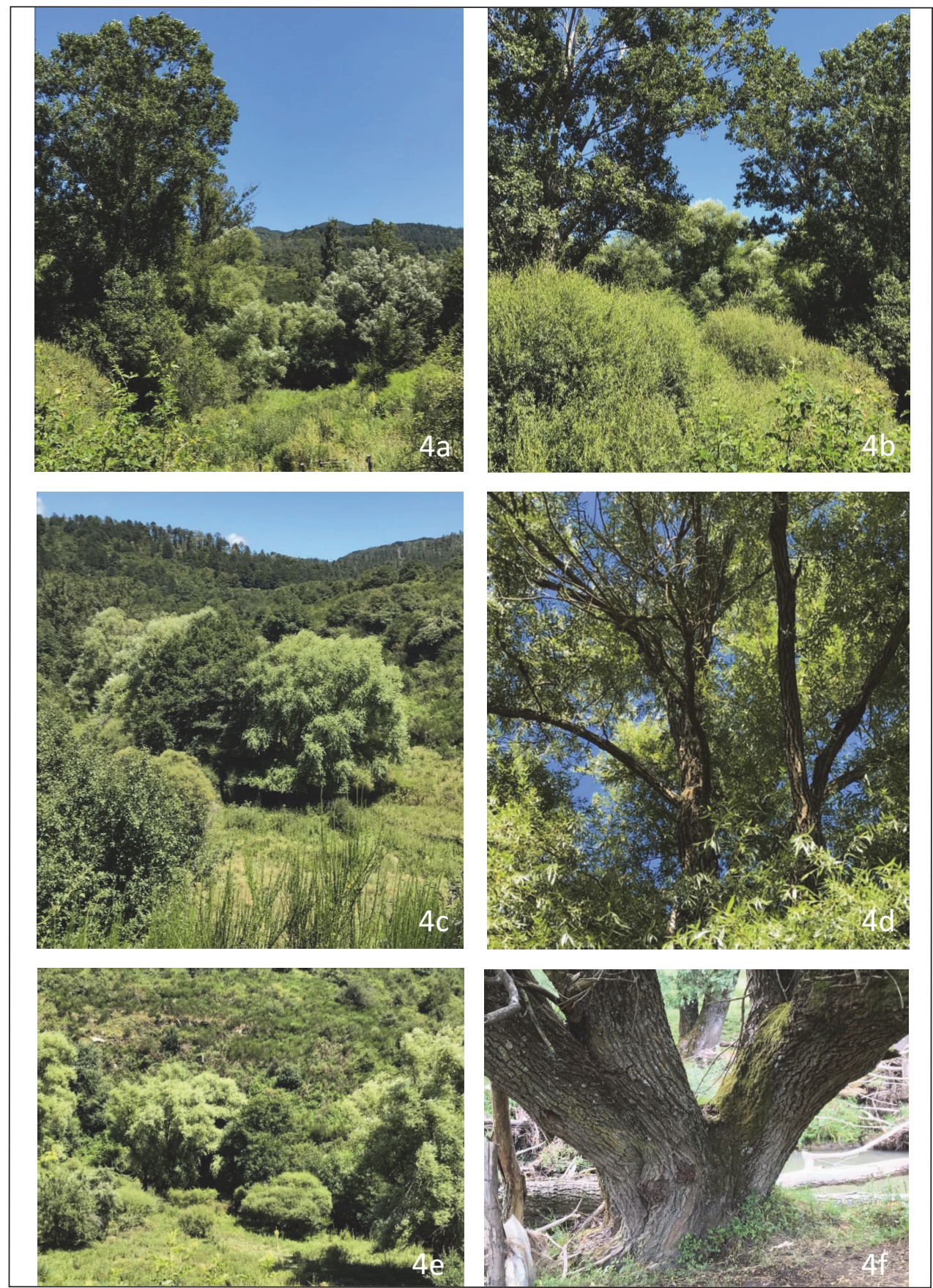

Fig. 4. General and particular aspects of Alno-Salicetum rubentis: a, b, c, e) plant landscape, structure of forest vegetation and main trees of Alnus glutinosa, Salix $\times$ rubens, S. alba and Polulus nigra; d) ancient big tree of Salix alba; f) polycormic base of the same ancient big tree of Salix alba. 


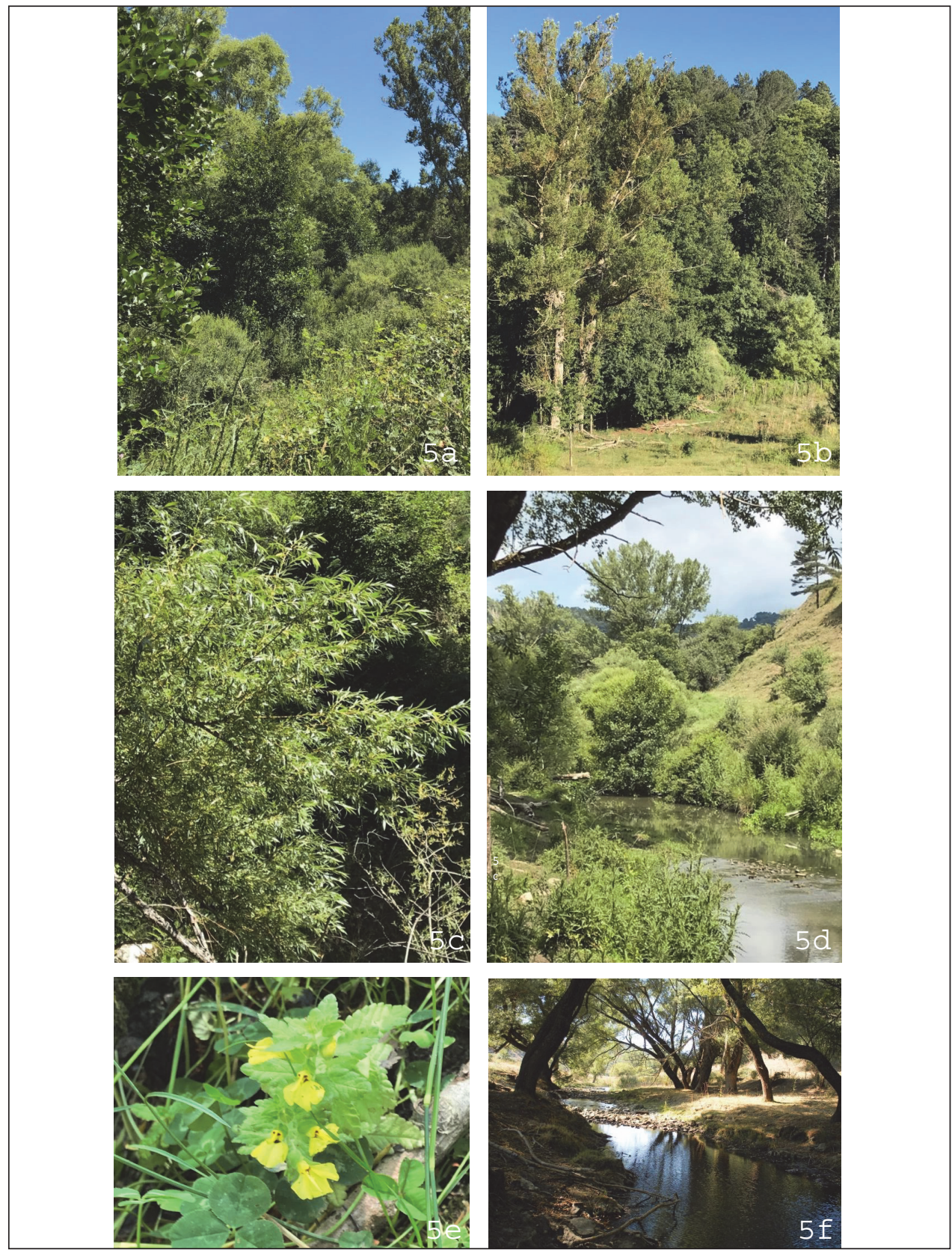

Fig. 5. General and particular aspects of Alno-Salicetum rubentis: a) plant landscape and structure of the association; b) in the foreground, on the left, exuberant Populus nigra trees; c) stems and leaves of Salix $\times$ rubens, characteristic tree species of the association; d) landscape of river vegetation in early summer at easthern slopes of Monte Azzarello; e) flowering plant of Rhyncochorys elephas, characteristic erbaceous species of the association; f) landscape of river vegetation in late summer at Piano Grande. 


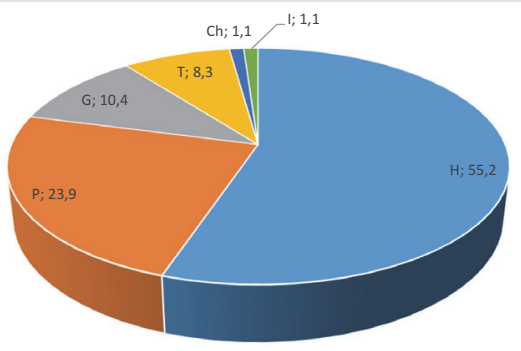

a) Biological qualitative (florula) spectrum of Alno-Salicetum rubentis.

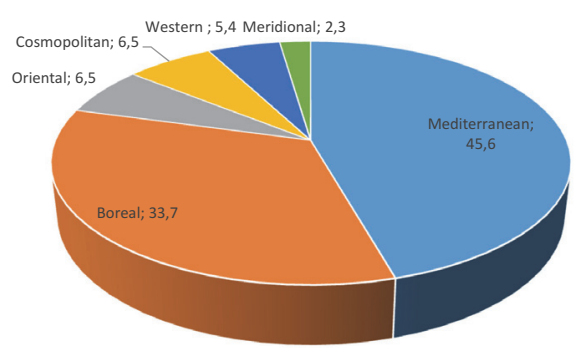

c) Chorological qualitative (florula) spectrum of Alno-Salicetum rubentis.

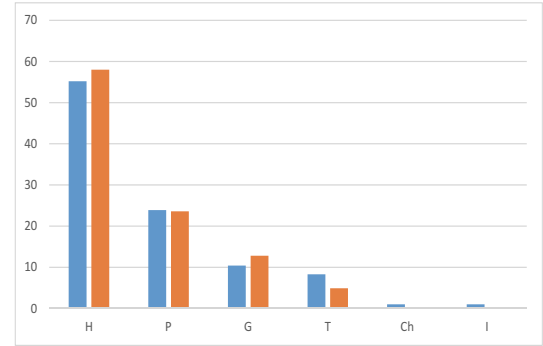

e) Comparison between qualitative (blue) and quantitative(orange) biological spectra of the Alno-Salicetum rubentis.

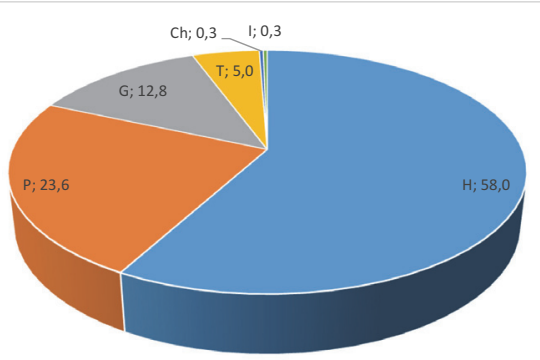

b) Biological quantitative (vegetation) spectrum of Alno-Salicetum rubentis.

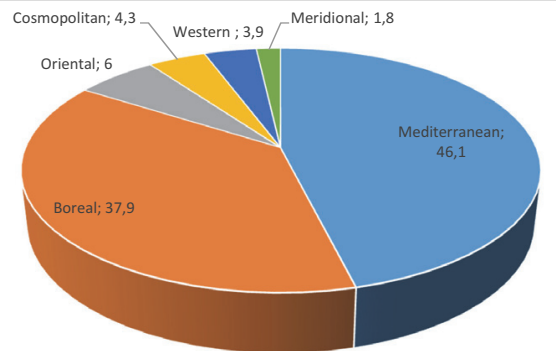

d) Chorological quantitative (vegetation) spectrum of Alno-Salicetum rubentis.

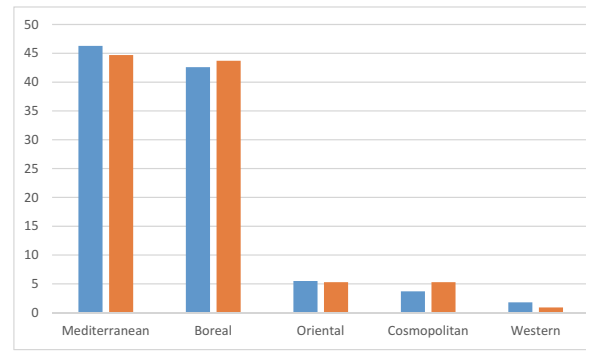

f) Comparison between qualitative (blue) and quantitative (orange) chorological spectra of the Alno-Salicetum rubentis.

Fig. 6. Graphic representation of biological and chorological spectra of Alno-Salicetum rubentis $(a, b, c, d, e, f)$. 


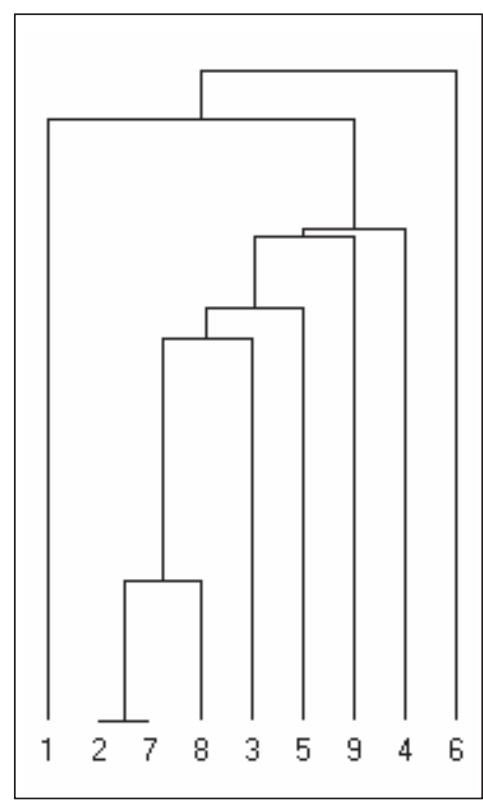

$1=$ Alno glutinosae-Salicetum rubentis (ass. nov.)

$2=$ Alnetum glutinoso-cordatae (from Brullo 2001)

3 = Alno-Salicetum tyrrhenicae (from Brullo 2001)

4 = Hyperico-Salicetum ionicae (from Brullo 2001)

5 = Polysticho-Alnetum glutinosae (from Brullo 2001)

6 = Euphorbio-Alnetum glutinosae (from Brullo 2001)

$7=$ Alnetum glutinoso-cordatae (from Brullo \& Spampinato 1997)

8 = Angelico sylvestris-Alnetum glutinosae (from Brullo \& Spampinato 1997)

9 = Ulmo canescentis-Salicetum pedicellatae (from Brullo \& Spampinato 1990)

Fig. 7. Dendrogram obatined by cluster analysis based on average linkage within merged groups (Podani 2000).

Syntaxonomical position - From Table 1, we can see that the species characteristic of the class Salici purpureae-Populetea nigrae are well represented. In particular, the order Populetalia albae is represented by Sambucus nigra, Carex pendula, C. remota, Equisetum telmateia, Hypericum hircinum subsp. majus, Solanum dulcamara and Symphytum bulbosum. The high frequency in the tree layer of Populus nigra and Salix alba (Figs 4d, 4f and 5a-b), respectively characterizing the class and the alliance Populion albae, allows us to include this new association in this alliance.

The rich presence of species of Querco roboris-Fagetea sylvaticae (= CarpinoFagetea sylvaticae) such as, Acer pseudoplatanus, A. campestre, Crataegus monogyna, Clematis vitalba, Hedera helix, Daphne laureola, Brachypodium sylvaticum, Lathyrus pratensis, Viola reichenbachiana, Geranium versicolor and Sanicula europaea (Table 1), suggests that it can be considered as a natural transformation of the surrounding climatic vegetation due to the effects of high level of water content in the soil.

Affinities - The Alno glutinosae-Salicetum rubentis in Sicily does not relate to other associations. It finds affinity with associations of Calabria, in particular with the Alnetum glutinoso-cordatae, the Alno-Salicetum tyrrhenicae, the HypericoSalicetum jonicae, the Euphorbio corallioides-Alnetum glutinosae and the AngelicoAlnetum glutinosae. In Sicily it has affinity only with the Ulmo canescentis-Salicetum pedicellatae from different area.

The dendrogram in Fig. 7 shows the distinction of the new Sicilian association (number 1) from the others in Southern Italy and the association of the same alliance previously described for Sicily (Brullo \& Spampinato 1990). 
Euonymo europaei-Salicetum lambertianae Raimondo, Domina \& Di Gristina ass. nov. hoc loco (Table 4).

Type: Rel. 5 in Table 4 (geographic coordinates: $37^{\circ} 57^{\prime} 38,57^{\prime \prime} \mathrm{N} / 14^{\circ} 54^{\prime} 28,24^{\prime \prime} \mathrm{E}$ ).

This association occupies the muddy-silty margins of streams and small flat channels, where water flows slowly on the surface for most of the year. Its physiognomy is due to Salix purpurea subsp. lambertiana (Figs. 8a-d) and Euonymus europaeus (Fig. $8 \mathrm{e})$.

Characteristic species - This association is characterized by few species. They are Euonymus europaeus, species of the Querco-Fagetea in other environmental and geographical contexts that in this association occurs with considerable frequency and with exuberant plants (Fig. 8e-f), Salix purpurea subsp. lambertiana, dominant in the arborescent layer and Euphorbia meuselii, an endemic shrubs, that also occurring in the south of the Italian peninsula, in mesophilic evergreen oak woods and deciduous oak woods. All the three species can be considered a territorial characteristic or local characteristic species.

Floristic organization - As can be seen in Table 4, the vegetation investigated is basically constituted by Salix purpurea which, as already mentioned, corresponds to a distinct taxon of subspecific level ( $S$. purpurea subsp. lambertiana). Several other woody, suffruticose and herbaceous species are associated with this willow. In the arborescent layer - besides Salix purpurea subsp. lambertiana - Euonymus europaeus and Rosa canina are very frequent. Occasionally $S$. alba and Alnus glutinosa are occurring as trasgressive from the Alno-Salicetum rubentis. Occasionally among the trees there is a presence of Malus crescimannoi and Pyrus ciancioi, two endemic trees frequent in the mantle vegetation of the contiguous woods. In the herbaceous layer, Euphorbia meuselii as well as Carex remota, species indicated as characteristic of the Apennine alleance Alno-Fraxinion (Pedrotti \& Gafta, 1996). Even some herbaceous species including Urtica dioica, Equisetum palustre, Agrostis stolonifera subsp. scabriglumis, Mentha spicata and Elymus repens, contribute to characterize the florula of this association.

Biological and biogeographical structure - The florula of this association is composed of species belonging to different biological categories among which always the hemicryptophytes (50\% and 42.3\%) (Table 5a, 9a) and the phanerophytes $(33.9 \%$ and $42.3 \%$ ) stand out both qualitatively and quantitatively (Table 5b, Fig. 9b); this last category, as for the previous association, determines the physiognomy of the vegetation of this association. From the biogeographical point of view, numerous chorotypes are represented, belonging to Mediterranean (46.3\% and 44.7\%) and the boreal chorotype (42.6\% and $43.7 \%$ ) emerge (Table 6a, Fig. $9 \mathrm{c}$ ). The phytogeographic spectrum comprises numerous geo-elements including the European, Eurasian, paleotemperate and cosmopolitan species. The role of the Mediterranean chorotype (euro and steno) is limited, but in some cases decisive (Table 6b, Fig. 9d); within it the endemic component is well reperesnted (Malus crescimannoi, Pyrus ciancioi, .Arrhenatherum elatius subsp. nebrodense and Euphorbia meuselii). 
Table 4. Phytosociological table of Euonymo-Salicetum lambertianae.

\begin{tabular}{|c|c|c|c|c|c|c|c|c|c|}
\hline $\begin{array}{l}\text { Biological } \\
\text { form }\end{array}$ & $\begin{array}{l}\text { Chorological } \\
\text { type }\end{array}$ & Relevé $\left(\mathrm{n}^{\circ}\right)$ & 1 & 2 & 3 & 4 & 5 & 6 & \multirow{7}{*}{$\begin{array}{l}3 \\
0 \\
0 \\
\\
\end{array}$} \\
\hline & & Altitude (m a.s.1.) & 1062 & 1293 & 1105 & 1108 & 1078 & 1153 & \\
\hline & & Exposure & $\mathrm{E}$ & NO & $\mathrm{N}$ & NW & $\mathrm{E}$ & SE & \\
\hline & & Slope $\left({ }^{\circ}\right)$ & 5 & 3 & 3 & 5 & 4 & 3 & \\
\hline & & Total cover $(\%)$ & 95 & 100 & 95 & 100 & 95 & 95 & \\
\hline & & Woody layer average height $(\mathrm{m})$ & 5,0 & 6,0 & 5,5 & 6,0 & 5,0 & 5,5 & \\
\hline & & Area $\left(\mathrm{m}^{2}\right)$ & 70 & 90 & 80 & 80 & 70 & 90 & \\
\hline & & Species per relevé & & & & & & & \\
\hline & & Char. and diff. species of association & & & & & & & \\
\hline $\mathrm{P}$ & Eurasiat. & Salix purpurea ssp. lambertiana & 4.5 & 5.5 & 4.5 & 5.5 & 4.5 & 4.5 & $\mathrm{~V}$ \\
\hline $\mathrm{P}$ & Eurasiat. & Euonymus europaeus (diff.) & 1.1 & 1.1 & 1.2 & & +.2 & +.2 & $\mathrm{~V}$ \\
\hline \multirow[t]{2}{*}{$\mathrm{Ch}$} & Endem. & Euphorbia meuselii (diff.) & 1.1 & +.2 & & 1.1 & +.2 & & IV \\
\hline & & Char, of the alliance, order and class & & & & & & & \\
\hline \multirow[t]{2}{*}{$\mathrm{P}$} & Paleotemp. & Salix alba & & 1.1 & & & 1.1 & & II \\
\hline & & $\begin{array}{l}\text { Trasgr. of Populion, Populetalia } \text { and } \\
\text { Salici purpureae-Populetea nigrae }\end{array}$ & & & & & & & \\
\hline $\mathrm{P}$ & Paleotemp. & Solanum dulcamara & 1.2 & 1.1 & 1.1 & + & & & IV \\
\hline $\mathrm{H}$ & NE-Medit.-Mont. & Rhynchocorys elephas & & +.2 & +.2 & +.2 & & +.2 & IV \\
\hline $\mathrm{G}$ & Stenomedit. & Euphorbia hirsuta & 1.1 & + & & & + & 1.2 & IV \\
\hline $\mathrm{P}$ & Eurasiat. & Salix caprea & & & 1.2 & 1.2 & & 1.2 & III \\
\hline $\mathrm{P}$ & Europ.-Caucas. & Sambucus nigra & & & & +.2 & 1.1 & & II \\
\hline $\mathrm{H}$ & Eurasiat. & Carex pendula & & +.2 & & +.2 & & & II \\
\hline $\mathrm{P}$ & Paleotemp. & Alnus glutinosa & & & 1.1 & & & & I \\
\hline $\mathrm{P}$ & Europ. & Salix $\times$ rubens & & & & & 1.1 & & I \\
\hline $\mathrm{P}$ & S-Europ.-Sudsib. & Fraxinus angustifolia & & & & & & 1.1 & I \\
\hline \multirow[t]{2}{*}{$\mathrm{P}$} & Eurimedit & Hypericum hircinum ssp. majus & & & & +.2 & & & I \\
\hline & & $\begin{array}{l}\text { Trasgr. of Querco roboris Fagetea } \\
\text { sylvaticae }\end{array}$ & & & & & & & \\
\hline $\mathrm{P}$ & Europ.-Caucas. & Acer campestre & 1.1 & 1.1 & 1.1 & & 1.1 & 1.1 & $\mathrm{~V}$ \\
\hline $\mathrm{P}$ & Paleotemp. & Rosa canina & 1.1 & 1.2 & 1.2 & 1.2 & & 1.2 & V \\
\hline $\mathrm{P}$ & Paleotemp. & Crataegus monogyna & + & 1.1 & & & 1.1 & & III \\
\hline $\mathrm{H}$ & Paleotemp. & $\begin{array}{l}\text { Brachypodium sylvaticum ssp. } \\
\text { sylvaticum }\end{array}$ & +.2 & & +.2 & & & +.2 & III \\
\hline $\mathrm{P}$ & Subatlant. & Daphne laureola & & & + & & +.2 & & II \\
\hline $\mathrm{P}$ & Europ.-Caucas. & Clematis vitalba & & & & & & 1.2 & I \\
\hline $\mathrm{P}$ & Eurimedit. & Rubus ulmifolius & & & & & & 1.2 & I \\
\hline $\mathrm{H}$ & Circumbor. & Prunella vulgaris $\mathrm{ssp}$. vulgaris & 1.1 & & & & & & I \\
\hline $\mathrm{H}$ & Circumbor. & Elymus caninus & +.2 & & & & & & I \\
\hline $\mathrm{Ch}$ & Eurimedit. & Ruscus aculeatus & & & +.2 & & & & I \\
\hline $\mathrm{H}$ & Paleotemp. & Sanicula europaea & & & & +.2 & & & I \\
\hline $\mathrm{G}$ & NE-Medit.-Mont. & Geranium versicolor & & & & + & & & I \\
\hline \multirow[t]{2}{*}{$\mathrm{H}$} & Endem. Sic. & Aquilegia sicula & & & & & + & & I \\
\hline & & Other species & & & & & & & \\
\hline $\mathrm{H}$ & Subcosmop. & Urtica dioica & 1.2 & +.2 & 1.2 & 1.2 & +.2 & & $\mathrm{~V}$ \\
\hline $\mathrm{H}$ & Endem. Sic. & Arrhenatherum elatius ssp. nebrodense & +.2 & +2 & +.2 & +.2 & & + & $\mathrm{V}$ \\
\hline $\mathrm{P}$ & & Rubus sp. & 1.2 & 1.2 & 1.2 & & 1.2 & & IV \\
\hline $\mathrm{G}$ & Circumbor. & Equisetum palustre & 1.2 & & 1.2 & 1.2 & & & III \\
\hline $\mathrm{H}$ & Euroasiat. & Mentha spicata & 1.2 & & & & 1.2 & +.2 & III \\
\hline $\mathrm{H}$ & Europ--Caucas. & Primula vulgaris $\mathrm{ssp}$. vulgaris & & & +.2 & +.2 & & 1.2 & III \\
\hline $\mathrm{H}$ & Circumbor. & Agrostis stolonifera ssp. scabriglumis & & +.2 & & +.2 & +.2 & & III \\
\hline $\mathrm{P}$ & Endem. Sic. & Malus crescimannoi & & & & 1.1 & & 1.1 & II \\
\hline $\mathrm{P}$ & & Pyrus sp. & 1.1 & & & & & + & II \\
\hline $\mathrm{H}$ & Endem. Sic. & Tanacetum vulgare ssp. siculum & +.2 & & +.2 & & & & II \\
\hline $\mathrm{H}$ & Eurasiat. & Plantago major & +.2 & & & & & +.2 & II \\
\hline G & Circumbor. & Elymus repens & & & +.2 & & & +.2 & II \\
\hline $\mathrm{H}$ & Eurasiat. & Rumex conglomeratus & + & & & + & & & II \\
\hline $\mathrm{G}$ & Circumbor. & Equisetum telmateia & & & & 1.2 & & & I \\
\hline $\mathrm{H}$ & Subendem. & Cirsium creticum ssp. triumfettii & & & & & & 1.2 & I \\
\hline G & Circumbor. & Juncus articulatus $\mathrm{ssp}$. articulatus & & & & & & 1.2 & I \\
\hline $\mathrm{H}$ & Eurimedit. & Mentha pulegium ssp. pulegium & & & & & & 1.2 & I \\
\hline $\mathrm{H}$ & Subcosmop. & Urtica dioica & & & & & & 1.2 & I \\
\hline $\mathrm{P}$ & Endem. Sic. & Pyrus ciancioi & & & 1.1 & & & & I \\
\hline $\mathrm{H}$ & Paleotemp. & $\begin{array}{l}\text { Lolium arundinaceum } \mathrm{ssp} . \\
\text { arundinaceum }\end{array}$ & +.2 & & & & & & I \\
\hline $\mathrm{H}$ & Paleotemp. & Ranunculus repens & +.2 & & & & & & I \\
\hline $\mathrm{H}$ & Eurosib. & Trifoilum pratense & & +.2 & & & & & I \\
\hline $\mathrm{T}$ & Paleotemp. & Persicaria lapathifolia & & +.2 & & & & & I \\
\hline $\mathrm{H}$ & Eurosib. & Juncus conglomeratus & & & & & +.2 & & I \\
\hline $\mathrm{H}$ & Paleotemp. & Mentha aquatica s.l. & & & & & +.2 & & I \\
\hline $\mathrm{P}$ & Europ.-Caucas. & Prunus spinosa ssp. spinosa & & & & & & +.2 & I \\
\hline $\mathrm{H}$ & Paleotemp. & Juncus inflexus ssp. inflexus & & & & & & +.2 & I \\
\hline $\mathrm{H}$ & Eurasiat. & Epilobium montanum & & & & & & +.2 & I \\
\hline $\mathrm{H}$ & Eurimedit. & Carex distans & & & & & & +.2 & I \\
\hline $\mathrm{H}$ & Paleotemp. & Epilobium hirsutum & + & & & & & & I \\
\hline $\mathrm{H}$ & Europa-Asia & Heracleum sphondylium ssp. elegans & & & & & & + & I \\
\hline
\end{tabular}


Table 5. Data of biological spectra of Euonymo-Salicetum lambertianae.

\begin{tabular}{|l|l|l|}
\hline Biological forms & \% florula & \% vegetation \\
\hline H & 50.0 & 42.3 \\
\hline P & 33.9 & 42.3 \\
\hline G & 10.7 & 10.3 \\
\hline Ch & 3.6 & 4.2 \\
\hline T & 1.8 & 0.9 \\
\hline
\end{tabular}

Table 6. Data of chorological spectra of Euonymo-Salicetum lambertianae.

\begin{tabular}{|l|c|c|}
\hline $\begin{array}{l}\text { Chorological } \\
\text { contingents }\end{array}$ & $\%$ florula & \% vegetation \\
\hline Mediterranean & 46.3 & 44.7 \\
\hline Boreal & 42.6 & 43.7 \\
\hline Oriental & 5.5 & 5.3 \\
\hline Cosmopolitan & 3.7 & 5.3 \\
\hline Western & 1.9 & 1.0 \\
\hline
\end{tabular}

Syntaxonomical position - The Euonymo europaei-Salicetum lambertianae is an association referable to the Salicion albae, alliance of the order Salicetalia purpureae. In the association, the only feature of the alliance present is Salix alba. Salix purpurea subsp. lambertiana physiognomizes this association and it is considered differential species; for this two roles the same taxon contributes to give its name. The described association is spatially and therefore also dynamically correlated to Alno-Salicetum rubentis, association of the same class Salici purpureae-Populetea nigrae, more evolved and referred to different order and alliance.

In the examined association, Carex pendula and Sambucus nigra - characteristics of the Populion and Populetalia albae -are to be considered transgressive. Also Acer campestre and Brachypodium sylvaticum are transgressive species, but of the climatic communities occurring to the margins of the association and referred to the Querco roboris-Fagetea sylvaticae class.

Affinities - The Euonymo europaei-Salicetum lambertianae has an affinity with the willow woods of Calabria (Brullo \& Spampinato 1997) framed in the alliance Salicion albae, where we find the following associations: Eriantho-Salicetum amplexicaulis, Alno-Salicetum jonicae, Salicetum albo-brutiae, and finally the Salicetum lambertiano-elaeagni. The new Sicilian association is relatively similar only with the Salicetum albo-purpureae occurring also in south Italy (Calabria).

Distances and affinities of the new association with other similar associations described for the southern regions of the Italian Peninsula and Sicily were calculated by processing with Similarity ratio (Podani 2000). From the dendrogram obtained 


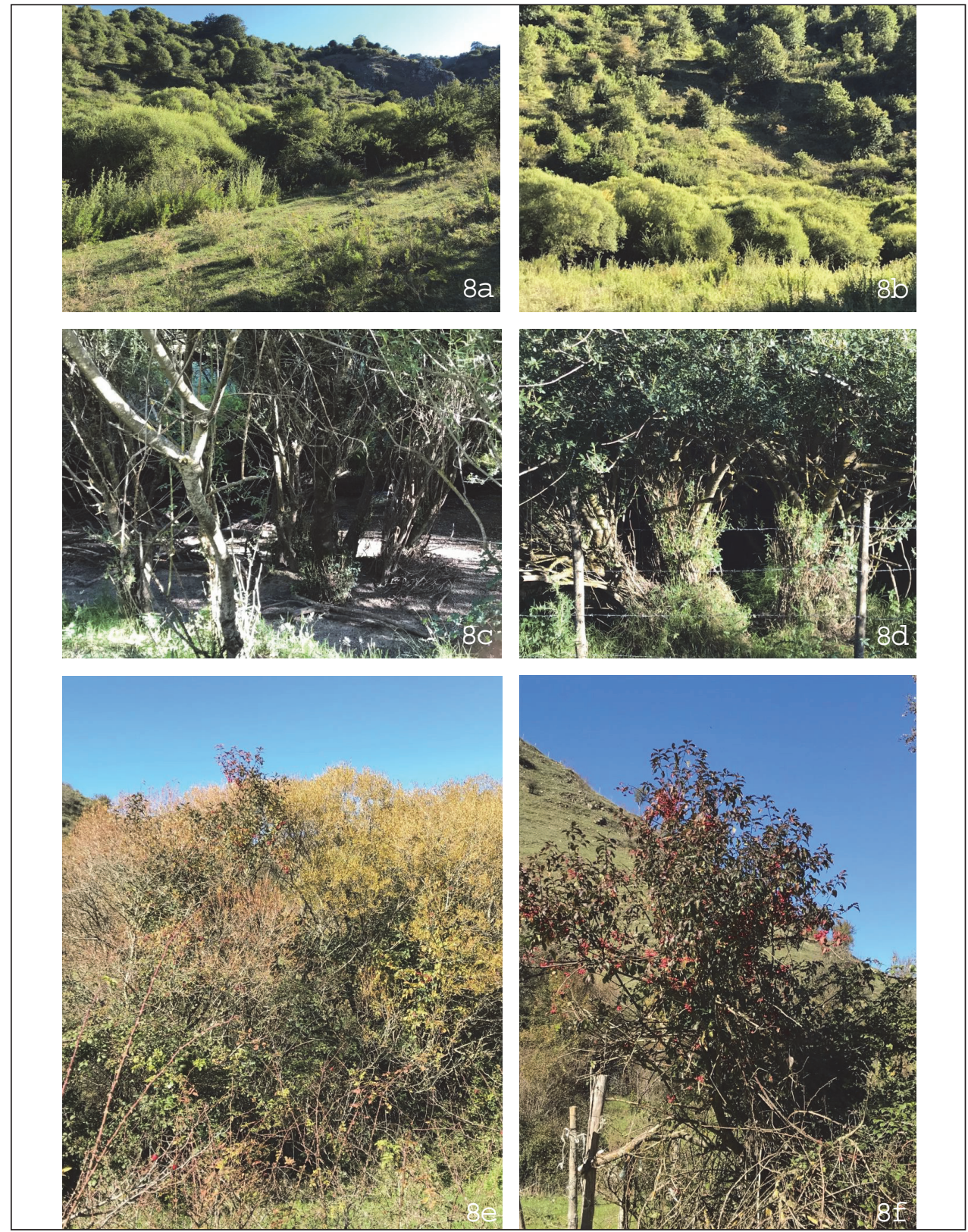

Fig. 8. General and particular aspects of Euonymo-Salicetum lambertianae: a) general plant landscape (northern slopes of Monte Colla); b) linear physiognomic aspect of the association; remarkable is the exclusive dominance of Salix purpurea subsp. lambertianae; c) structure of the basal layer of the arborescent vegetation; d) basal layer of the arborescent vegetation of the association; e) autumnal arborescent aspect of the association: in the foreground Salix purpurea subsp. lambertiana with Euonymus europaeus; f) vigorous small tree of Euonymus europaeus in autumn. 


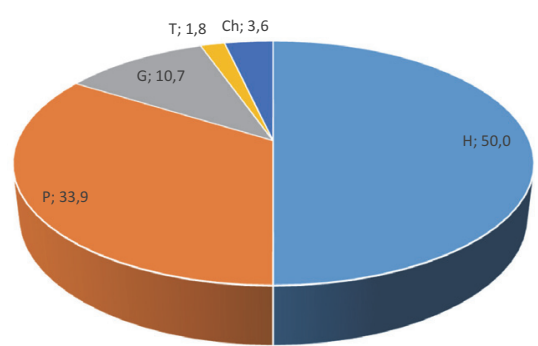

a) Biological qualitative (florula) spectrum of Euonymo-Salicetum lambertianae.

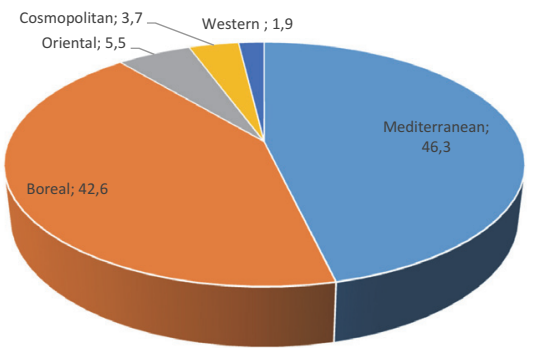

c) Chorological qualitative (florula) spectrum of Euonymo-Salicetum lambertianae.

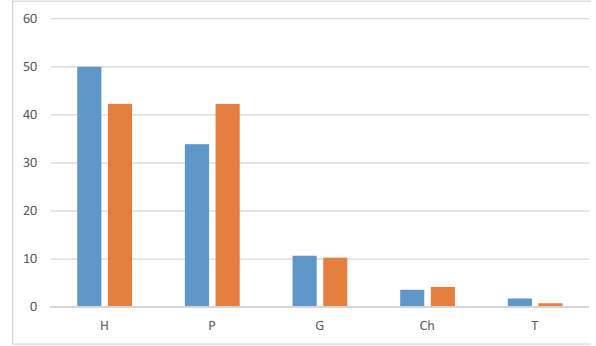

e) Comparison between qualitative (blue) and quantitative (orange) biological spectra of the Euonymo-Salicetum lambertianae.

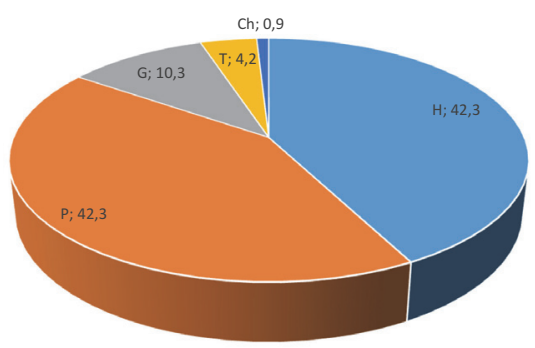

b) Biological quantitative (vegetation) spectrum of Euonymo-Salicetum lambertianae.

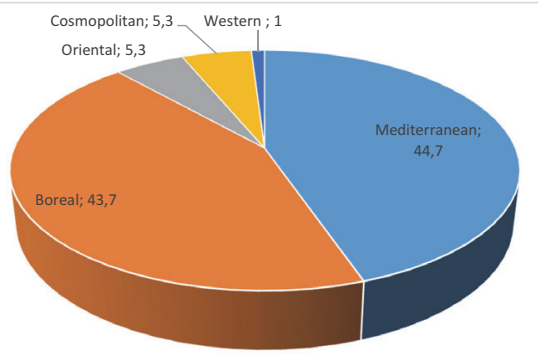

d) Chorological quantitative (vegetation) spectrum of EuonymoSalicetum lambertianae.

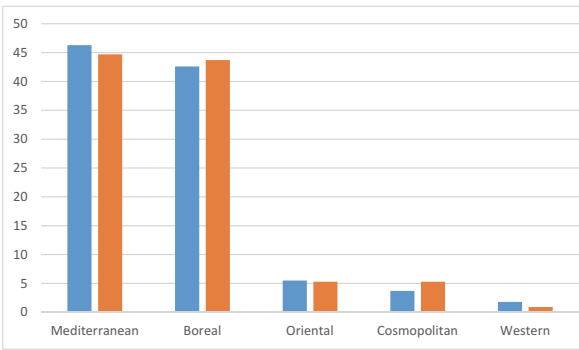

f) Comparison between qualitative (blue) and quantitative (orange) chorological spectra of the Euonymo-Salicetum lambertianae.

Fig. 9. Graphic representation of biological and chorological spectra of Euonymo-Salicetum lambertianae (a, b, c, d, e, f). 
(Fig. 10), the distinction of the new Sicilian association is clear from the other in Southern Italy, and the association of the same alliance previously described for Sicily (Brullo \& Spampinato 1990). The peninsular associations mentioned above have a greater affinity between them. As with Alno glutinosae-Salicetum rubentis, also in this case the other associations mentioned above have greater affinity with each other.

\section{Discussion and conclusions}

In the studies on the vegetation of the waterbodies of Sicily - filed to the most diffused aspects, mainly included in the thermo and meso-Mediterranean phytoclimatic belts analyses of submontane phytocoenoses (Supramediterranean), actually little diffused in the Island, were missing. The vegetation previously studied had been framed in various units of Populetalia albae, Salicetalia purpureae and Nerio-Tamaricetalia, orders also referring to Querco roboris-Fagetea sylvaticae, Salicetea purpureae and NerioTamaricetea classes. In light of the new acquisitions, this approach is superseded only as regards the first order placed in two distinct classes: the prodrome of the Italian vegetation (Biondi \& al. 2014) refers it to Salici purpureae-Populetum nigrae, several other authors to Alno glutinosae-Populetum albae (Bournérias \& al. 2001; Mucina \& al. 2016; Reymann \& al. 2016).

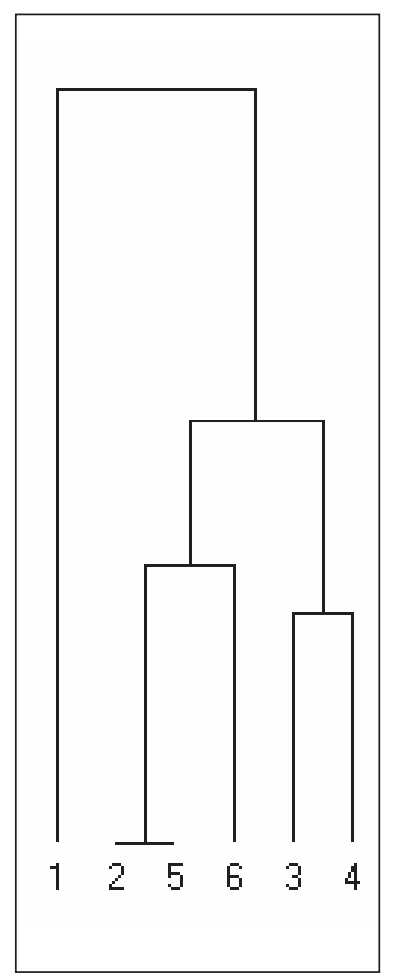

1 = Euonymo europaei-Salicetum lambertianae (ass. nov.)

2 = Salicetum albo-brutiae (from Brullo \& al. 2001)

3 =Eriantho-Salicetum amplexicaulis (from Brullo \& al. 2001)

4 = Alno-Salicetum ionicae (from Brullo \& al. 2001)

5 = Salicetum lambertiano-elaeagni (from Brullo \& Spampinato 1997)

6 = Salicetum albo-purpureae (from Brullo \& Spampinato 1990)

Fig. 10. Dendrogram obtained by cluster analysis based on average linkage within merged groups (Podani 2000). 
The study presented here, examines unprecedented aspects located in the Nebrodi Mountains, the largest and wettest mountain system in Sicily and, consequently, covered by wide forests. It is not a case that the largest and most important waterways of the island originate from it, including the Alcantara river and some tributaries of the Simeto river.

The phytosociological study of the riparian vegetation of the small watercourses examined - the only ones with a permanent regime, although with large fluctuations in water flow during the year - allowed to highlight the presence of phytocoenoses not yet detected on the Island. These are two related associations: the first one is the real forestry aspect. The two associations have floristic and ecological affinities with recurrent communities in the southern Apennines (Brullo \& Spampinato 1997), in particular in Calabria, the extreme region of the Italian peninsula close to Sicily. In this region, similar aspects have been described in Sila (Barbagallo \& al. 1990) and Aspromonte (Brullo \& Spampinato 1997; Brullo \& al. 2001). From a phytosociological point of view, the two associations described here are also linked to some recurring associations in other areas of the same Nebrodi district and other sectors of Sicily (Brullo \& Spampinato 1990; Gianguzzi 1999; Gianguzzi \& al. 2004). Nevertheless, unlike the associations already known - including the Salicetum albo-pedicellatae and the Saliceto pedicellatae-purpureae - the associations described are more mesophilic and justify their classification in two distinct classes - respectively Alno glutinosae-Populetea albae and Salicetea purpureae. In particular, the association Alno glutinosae-Salicetum rubentis, framed here in the alliance Populion albae (Populetalia albae); therefore, the Euonymo europaeiSalicetum lambertianae in the alliance Salicion albae (Salicetalia purpureae).

Also based on the results presented here, we can conclude by offering a new syntaxonomic framework of the riparian vegetation of the waterways of Sicily. It takes into account the higher order units established after the first syntaxonomic gradings received by the various associations at the time of their respective descriptions.

\section{AZONAL VEGETATION (ALLUVIAL FORESTS AND SHRUBS) IN SICILY SYNTAXONOMIC FRAMEWORK PROPOSED $(*)$}

SALICI PURPUREAE-POPULETEA NIGRAE Rivas Mart. \& Cantò ex Rivas Mart. \& al. 1991

POPULETALIA ALBAE Br.-B1. \& Tchou 1949

POPULION ALBAE Br.-Bl. ex Tchou 1949

Roso sempervirentis-Populetum nigrae Pedrotti \& Gafta 1992

Alno glutinosae-Salicetum rubentis Raimondo, Domina \& Di Gristina ass. nov. hoc loco

PLATANION ORIENTALIS I. Kárpati \& V. Kárpati 1961

Platano- Salicetum pedicellatae Barbagallo, Brullo \& Fagotto 1979

Platano-Salicetum gussonei Brullo \& Spampinato 1990 
OSMUNDO-ALNION GLUTINOSAE Dierschke \& Rivas-Martínez 1975

Osmundo regalis-Salicetum pedicellatae Brullo \& Spampinato 1990

SALICETALIA PURPUREAE Moor 1958

SALICION ALBAE Soó 1951

Salicetum albo-purpureae (I. Kárpati \& V. Kárpati 1961) Barbagallo, Brullo \& Fagotto 1979

Euonymo europaei-Salicetum lambertianae Raimondo, Domina \& Di Gristina ass. nov. hoc loco

SALICION PEDICELLATAE Rivas-Martínez \& al. 1984

Salicetum albo-pedicellatae Brullo \& Spampinato 1990

Ulmo canescentis-Salicetum pedicellatae Brullo \& Spampinato 1990

Agropyro panormitani-Salicetum pedicellatae Brullo \& Spampinato 1990

NERIO-TAMARICETEA Br.-B1. \& O. Bolòs 1958

NERIO OLEANDRI -VITICETALIA AGNI-CASTI De Foucault, Bensettiti \& Paradis 2012 RUBO ULMIFOLII-NERION OLEANDRI O. Bolòs 1985

Sparti-Nerietum oleandri Brullo \& Spampinato 1990

TAMARICETALIA Br.-Bl. \& O. Bolòs 1958 em. Izco, Fernández-González \& A. Molina 1984

TAMARICION AFRICANAE Br.-Bl. \& O. Bolòs 1957

Tamaricetum gallicae Br.-Bl. \& O. Bolòs 1957

Aggr. a Tamarix africana Brullo \& Spampinato 1990

*This scheme is inspired to the syntaxonomic framework proposed for Italian vegetation by Biondi \& al. (2014).

From the syntaxonomic framework presented above, in Sicily, the Salicion albae alliance is represented by the Salicetum albo-purpureae and by the Euonymo europaei-Salicetum lambertianae, the new association described here for the Nebrodi Mountains.

\section{Acknowledgments}

Work carried out with the support of PLANTA/Center for Research, Documentation and Training (Palermo, Italy). The authors are grateful to Professor Franco Pedrotti for the encouragement received, and Professor Enrico Feoli for the critical reading of the article. A special thank to student Enrico Bajona (University of Palermo), for his preparation of the Fig. 3 prepared by Google Earth Pro.

\section{References}

Barbagallo, C., Brullo, S., Furnari, F., Longhitano, N. \& Signorello, P. 1982: Studio fitosociologico e cartografico della vegetazione (1:25.000) del territorio di Serra S. Bruno (Calabria). - In: C.N.R., s. 
AQ/1/227, Coll. Programma Finalizzato "Promozione della Qualità dell'Ambiente". Roma.

Bazan, G., Marino, P., Guarino, R., Domina, G. \& Schicchi, R. 2015: Bioclimatology and vegetation series in Sicily: a geostatistical approach. - Ann. Bot. Fenn. 51: 1-18. https://doi.org/10.5735/085.052.0202

Biondi, E., Blasi, C., Allegrezza, M., Anzellotti, I., Azzella, M. M., Carli, E., Casavecchia, S., Copiz, R., Del Vico, E., Facioni, L., Galdenzi, D., Gasparri, R., Lasen, C., Pesaresi, S., Poldini, L., Sburlino, G., Taffetani, F., Vagge, I., Zitti, S. \& Zivkovic, L. 2014: Plant communities of Italy: The Vegetation Prodrome. - Pl. Biosyst. 148(4): 728-814. https://doi.org/ 10.1080/11263504.2014.948527

Bournérias, M., Arnal, G. \& Bock, C. 2001: Guide des groupements végétaux de la région parisienne. - Paris.

Brullo, S. \& Grillo, M. 1978: Ricerche fitosociologiche sui pascoli dei monti Nebrodi (Sicilia settentrionale). - Not. Fitosoc. 13: 23-61.

— \& Spampinato, G. 1990: La vegetazione dei corsi d'acqua della Sicilia. - Boll. Accad. Gioenia 23(336): 192-251.

— \& - 1997: Indagine fitosociologica sulle ripisilve della Calabria (Italia meridionale). - Lazaroa 18: 105-151.

— \& - 1999: Syntaxonomy of higrophilous woods of the Alno-Quercion roboris. - Ann. Bot. (Rome) 57: 133-146.

—, Cirino, E. \& Longhitano, N. 1995: Vegetazione della Sicilia: quadro sintassonomico. - Atti Convegni Lincei 115: 285-305.

—, Scelsi, F. \& Spampinato, G. 2001: La vegetazione dell'Aspromonte. - Reggio Calabria.

Di Martino, A. \& Raimondo, F. M. 1976: Le infestanti delle colture di frumento della Sicilia occidentale. - Not. Fitosoc. 11: 45-74.

— \& - 1979: Biological and chorological survey of the Sicilian flora. - Webbia 34(1): 309-335. https://doi.org/10.1080/00837792.1979.10670174

Domina, G., Venturella, G. \& Gargano, M. L. 2018: Synthetic cartography for mapping biodiversity in the Mediterranean region: Sicily as a case study. - PhytoKeys 109: 77-92. https://doi.org/10.3897/phytokeys.109.28297

Giaimi, G. 1994: Il Parco dei Nebrodi. - Palermo.

Gianguzzi, L. 1999: Flora e Vegetazione dei Nebrodi. Itinerari didattici. Regione Siciliana, Assessorato Agricoltura e Foreste. - Palermo.

—, La Mantia, A. \& Lo Presti, R. M. 2004: Distribuzione, ecologia e status conservativo di Petagnaea gussonei (Sprengel) Rauschert (Apiaceae). - Naturalista sicil., s 4, 28(1): 205-242.

Karadelev, M., Rusevska, K., Venturella, G., Torta, L. \& Gargano, M. L. 2017: First record of Capnobotrys dingleyae (Metacapnodiaceae) on Taxus baccata for southern Europe. - Pl. Biosyst. 151(6): 941-943. https://doi.org/10.1080/11263504.2017.1289274

Mucina, L., Bültmann, H., Dierßen, K., Theurillat, J-P., Raus, T., Čarni, A, Šumberová, K., Willner, W., Dengler, J., Gavilán Garcìa, R., Chytrý, M., Hájek, M., Di Pietro, R., Iakushenko, D., Pallas, J., Daniëls, F. J. A., Bergmeier, E., Santos Guerra, A., Ermakov, N., Valachovič, M., Schaminée, J. H. J., Lysenko, T., Didukh, Y. P., Pignatti, S, Rodwell, J. S., Capelo, J., Weber, H. E., Solomeshch, A., Dimopoulos, P., Aguiar, C., Hennekens, S. M. \& Ticýh, L. 2016: Vegetation of Europe: hierarchical floristic classification system of vascular plant, bryophyte, lichen, and algal communities. - Appl. Veg. Sci. 19 (Suppl. 1): 3-264. https://doi.org/10.1111/avsc.12257

Pedrotti, F. \& Gafta, D. 1996: Ecologia delle foreste ripariali e paludose dell'Italia. - L'Uomo e l'Ambiente (Camerino) 23: 1-165.

Pignatti, S. 2017: Flora d'Italia, 2a ed., 2. - Milano.

Podani, J. 2000: Introduction to the exploration of multivariate biological data. - Leiden.

Raimondo, F. M., Domina, G. \& Spadaro, V. 2010: Checklist of the vascular flora of Sicily. - Quad. Bot. Amb. Appl. 21(2010): 189-252. 
-, Schicchi, R. \& Bazan, G. 2010: Analisi della vegetazione ripicola dell'alto Alcantara (Nebrodi, Sicilia). - In: Countdown 2010 save biodiversity. Il contributo della scienza della vegetazione, Università degli Studi di Pavia, Dipartimento di Ecologia del Territorio. - Pavia.

Reymann, J., Panajotis, C., Bioret, F., Bacchetta, G., Delage, A., Delbosc, P., Gamisans, J., Gauberville, C., Hugot, L., O’Deye-Guizien, K., Piazza, C. \& Pioli, A. 2016: Prodrome des Végétations de Corse. - Doc. Phytosoc. Sér. 3, 4: 1-176. https://doi.org/ 10.3406/ecmed.2018.2028

Rivas-Martínez, S. 1981: Les étages bioclimatiques de la végétation de la Péninsula Ibérique. - Anales Jard. Bot. Madrid 37(2): 251-268.

- 1982: Etages bioclimatiques, secteurs chorologiques et series de vegetation de l'Espagne méditerranéenne. - Ecol. Medit. 8(1-2): 275-288. https://doi.org/10.3406/ecmed.1982.1954

Schicchi, R. 2004: Materiali per una carta tematica delle emergenze floristiche e vegetazionali del parco dei Nebrodi. - Naturalista Sicil., s.4., 28(1): 39-163.

Walter, H. \& Lieth, H. 1960: Klimadiagramm-Weltatlas. - Jena.

Addresses of the authors:

Francesco M. Raimondo ${ }^{1}$, Gianniantonio Domina ${ }^{2}$ \& Emilio Di Gristina ${ }^{2 *}$, ${ }^{1}$ PLANTA/Center for Research, Documentation and Training, Via Serraglio Vecchio 28, 90123 Palermo, Italy. E-mail: raimondo@centroplantapalermo.org ${ }^{2}$ Department of Agricultural, Food and Forest Sciences (SAAF), University of Palermo, Viale delle Scienze, bld. 4, 90128 Palermo, Italy. E-mail: emilio.digristina@unipa.it; gianniantonio.domina@unipa.it

*Corresponding author.

\section{Locality, date and author/s of the reliefs in tables 1 and 4.}

Table 1 (Alno glutinosae-Salicetum rubentis)

Rel. 1: Contrada Costa del Salice, 20 June 2019, Di Gristina \& Raimondo

Rel. 2: Torrentello in Contrada Costa del Salice, 20 June 2019, Di Gristina \& Raimondo

Rel. 3: Piano Grande, 20 June 2019, Di Gristina \& Raimondo

Rel. 4: Torrente Inganno 24 June 2009, Raimondo

Rel. 5: Piano Grande: 24 June 2009, Raimondo

Rel. 6: Vallone sotto Monte Azzarello 24 June 2009, Raimondo

Rel. 7: Vallone sotto Monte Acquafredda, 27 June 2019, Domina \& Raimondo

Rel. 8: Torrente Favoscuro, 27 June 2019, Domina \& Raimondo

Table 4 (Euonymo europaei-Salicetum lambertianae)

Rel. 1:Torrentello in Contrada Costa del Salice, 20 June 2019, Di Gristina \& Raimondo

Rel. 2: Incisione sul versante nord di Monte Colla, 24 June 2009, Raimondo

Rel. 3: Vallone confluente nel Torrente Inganno, 24 June 2009, Raimondo

Rel. 4: Incisione a valle di Monte Bissalacqua, 20 June 2019, Di Gristina \& Raimondo

Rel. 5: Incisione a valle di Monte Musarra, 27 June 2019, Domina \& Raimondo

Rel. 6: Vallone confluente nel Torrente Favoscuro, 27 June 2019 Domina \& Raimondo 
